\author{
Kuzin 0., \\ Lukiyanets B., \\ Kuzin $\mathbf{N}$.
}

\title{
CONTINUAL DESCRIPTION OF POLYCRYSTALLINE SYSTEMS TAKING INTO ACCOUNT THEIR STRUCTURE
}

Об'єктом дослідження є поведінка границь зерен, умови утворення міжзеренних пошкоджень і інтеркристалітне руйнування полікристалічних сплавів при дї силових навантажень. Проблема створення внутрішніх граничних зон із заданими термодинамічними, фізичними і механічними характеристиками в сплавах, вирішення якої є найбільш перспективним способом підвищення їх властивостей, вимагає використання методів математичного моделювання. Це дозволить кількісно оцінювати вплив хімічного складу, термічної обробки та зовнішніх навантажень на утворення міжзеренних пошкоджень полікристалічних систем.

В ході дослідження на основі енергетичного підходу опису континуальних середовищ, із врахуванням фізичних ефектів, що відбуваються у масштабах, співрозмірних із структурними складовими та їх гранииями, побудовані математичні співвідношення моделі полікристалічних систем. Ця модель є основою для розрахунків і встановлення напружено-деформованого стану матеріалу на мезорівні. Показано, що на механічну поведінку матеріалів мають вплив не тільки абсолютні значення параметрів властивостей окремих мікрооб'ємів тіл, але і їх градієнт.

Отримано зв'язок між присутністю в покращувальних сталях гранищь зерен з підвищеним рівнем енергї $і$ здатністю до утворення міжзеренних пошкоджень при дї зовнішнього навантаження. Розроблено конщептуальний підхід до керування властивостями внутрішніх поверхонь розділу сплавів зміною їх структурно-енергетичного стану. Це пов'язано із тим, що запропоновані модельні $і$ експериментальні залежності основані на фізично обгрунтованому параметрі - відносному градієнті властивостей, який визначається сегрегащією домішок, виділенням фаз, густиною дислокацій в приграничних зонах зерен.

Встановлені граничні значення характеристик локальних об'ємів зерен, при яких зменшується здатність до утворення міжзеренних пошкоджень і інтеркристалітного руйнування сплавів. Завдяки цьому забезпечується можливість впровадження інноваційних технологій зернограничного конструювання структури металовиробів. Це дозволяє, у порівнянні з відомими технологіями, суттєво підвищувати параметри надійності деталей машин - довговічність, ресурс, безвідмовність при мінімальних економічних витратах.

Ключові слова: математичні співвідношення моделі полікристалічних систем, стан границь зерен полікристалів, міжзеренне руйнування.

\section{Introduction}

Rational construction of metallic materials is closely connected with the fundamental scientific problem of choosing an adequate mathematical description of polycrystalline systems, which allows their calculation and optimization with respect to operating conditions.

In this case, the modeling and evaluation of the behavior of such systems must necessarily be carried out taking into account the physical effects occurring at scales that are commensurate with the structural components and their boundaries.

Since it is at the level of structural components that the basic properties are formed.

Let's note that the possibility of a controlled change in the geometric and physical parameters of the interfaces of the structural components is an important reserve for improving the working properties of hardware. In this connection, these issues were transformed into a separate scientific direction in materials science - «engineering of grain boundaries and grain-boundary design of materials» $[1,2]$.

This scientific direction is in demand when developing innovative technologies for producing metal products with predetermined properties, evaluating the residual life of structures and determining the mechanisms and causes of failure of parts and equipment.

Under the conditions of the external load, dislocations form in the parts from the grain boundaries, and due to the difference in the elastic characteristics between the grains of polycrystals, stress concentrations arise. Predicting the behavior of polycrystals makes it necessary to establish the relationship between the structure, energy parameters of grain boundaries, physical properties and factors determining resistance to the formation of secondary damage. Therefore, the development and application of mathematical models that are suitable for such complex problems of interdisciplinary nature, such as the management of the structural-energy state of the internal interfaces, is relevant.

\section{The object of research and its technological audit}

The object of research is the behavior of grain boundaries, the conditions for the formation of intergranular damage and the intercrystalline destruction of polycrystalline alloys under the influence of force loads.

In order to more fully take into account all the features of the behavior of polycrystalline materials under 
operating conditions in the scientific literature, the following hierarchical levels of consideration of materials have been adopted [3]:

1. Macro level. At this level, the material is considered as a continuous (continuous) medium with properties whose parameters vary slightly in space; the typical size of a piece of material is commensurate with the entire product.

2. Meso level. The material is considered as a discretecontinuum medium (a discrete-continuum model description is used with additional physical conditions in the areas corresponding to the boundaries of the structural components - the boundary zones). The level of consideration of this scale level of material corresponds to the structural components and their boundaries.

3. Nano level. The level of consideration of the material corresponds to individual atoms (or their groups). At this level, the discrete model description is mainly used.

Let's note that the simultaneous model and calculation consideration of all three levels of material is a complex scientific problem, and therefore is currently used mainly in the theoretical direction [3].

In applied research, only one of the hierarchical levels is considered using the results obtained from analyzing the behavior of the material at other large-scale levels.

In many cases, the destruction of parts is due to the occurrence of cracks in places of local changes in the mechanical properties of products. Borders and junctions of grains, in which the accumulation and restructuring of defects under the influence of technological and operational loads leads to the appearance of damage and the development of intercrystalline cracks, may be among the most problematic places.

\section{The aim and objectives of research}

The aim of research is development of an approach to the continual description of locally inhomogeneous media for studying the behavior of polycrystalline materials taking into account the energy of grain boundaries.

To achieve this aim, the following objectives are formulated:

1. To build a mathematical model of the mechanics of polycrystalline spatial-gradient systems.

2. On the basis of the constructed model, to develop an approach to solving the problem of the formation of grain-boundary damage in polycrystalline alloys in the presence of a gradient of properties in individual microvolumes.

3. To investigate the main trends and the corresponding regularities of the influence of the relative gradient of the properties of the grain-grain boundary zone on the resistance to the formation of intergranular damage and the intercrystallite destruction of industrial alloys.

\section{Research of existing solutions of the problem}

The structural features of metallic polycrystalline systems at the scale level of grain - grain boundaries are of extremely important (and in some cases decisive) importance for the behavior of the entire material [2, 3]. In this regard, the construction of model approximations is carried out that allow to describe the behavior of polycrystalline materials at the meso level.
Exact calculated mathematical model approximations in the study of the behavior of polycrystals at this level are currently an open scientific problem. Depending on the purpose of describing the structure of the material and the approaches used, such characteristics of the structure as grains, grain boundaries are interpreted differently, which leads to a significant discrepancy when comparing model representations presented in various scientific publications.

Let's dwell in detail on such basic definitions for polycrystalline systems as grains and their boundaries.

The term «grain», according to [4,5], will be understood as a separate crystallite of a polycrystalline conglomerate, has one crystallographic orientation, and is separated from other crystals by boundaries. Grain size can range from a few micrometers to centimeters.

The term «grain boundary» is understood as the subsurface region, on both sides of which crystal lattices differ in their spatial orientation [5].

The size of this near-surface region, according to the physical representations of various literary sources [6, 7], can vary significantly. So, at the moment it is customary to separate the «static thickness» of the border, which has a thickness of several atomic parameters, and the «dynamic thickness». It is more «static» and is characterized by the vibrational spectrum of atoms in this layer; it differs from the vibrational spectrum of atoms in the central part of the grain [8].

It should be noted that the «dynamic thickness» is especially pronounced for the high angle grain boundaries, which have large differences in structure than other boundaries [9].

In this connection, the concept of a «grain boundary» should be expanded and the term «boundary - boundary region» should be used, which in many cases reaches several micrometers [10].

After establishing the dimensional characteristics of the boundary zone, the problem of the model of the structure of this zone is important.

In this work, let's use the Cox - Hirth model [11, 12], according to which the grain is divided into two subregions: the boundary zone and the inner part of the grain. Most dislocations are concentrated in the frontier zone [13], which as a result receives a gradient change in the parameters over depth and concentrates the defective structures directly at the boundary.

Currently, a significant amount of experimental data on the effect of grain boundaries with different energies on the behavior of polycrystalline materials in the process of plastic deformation is accumulated [4, 6]. It is shown that the strength and ductility of polycrystalline alloys depends on the proportion of low-energy boundaries, which are characterized by high resistance to destruction [8].

The creation of low-energy grain boundaries during technological processing is laid down in the principles of grain-boundary design of the structure of metal products. It should be noted that the question of the role of the structure of grain boundaries with a high level of energy and their boundary zones in the processes of secondary granulation remains open. Although the transition to the destruction of the grain boundaries is accompanied by a sharp deterioration in the mechanical properties and reliability of products [10].

From the standpoint of physical materials science at the energy level, the structure of this zone determines the 
value of the free energy of the grain boundary. Moreover, the higher its level, the more it is considered that the border contains more defects [14].

The condition (criterion) of local destruction is written in the form [14]:

$$
A_{H} \geq 2 \lambda_{L}-\lambda_{B},
$$

where $A_{H}$ - the work load; $\lambda_{L}$ - free energy (surface energy) of the material; $\lambda_{B}$ - free energy of the grain boundary.

As can be seen from relation (1), when the structure is defective in the boundary area of critical value, it responds at the energy level of the surface energy, the process of destruction begins in the body.

Taking into account relation (1), it is also possible to write down the force criteria of destruction.

\section{Methods of research}

Let's take into account the degradation of metallic materials at the structure level using a variable scalar nature - damageability.

The introduction of a scalar variable to assess changes in the structure of the material during loads is proposed in $[15,16]$, which currently have not lost their importance, given their experimental and applied significance.

When constructing the mathematical relationships of the model of polycrystalline materials, let's use the energy approach, which has shown its effectiveness in mathematical models of continual media, taking into account interrelated fields of various nature, the defectiveness of the structure of solids [17, 18].

Let's build a model considering only power loads.

Let's introduce the function of the free energy of the system, which depends both on the strain history and its current value:

$$
f(t)=\int_{0}^{t} K(t, \tau) g(\dot{e}) \mathrm{d} \tau
$$

where $K(t, \tau)$ - the core of heredity; $g(\dot{e})$ - function, energetically takes into account changes in internal parameters; $\dot{e}-$ strain tensor.

For the proposed model, let's accept the fading memory hypothesis, according to which the system conditions more distant in time have less influence on the current value of the variables at a given point in time.

Let's take a priori the additivity property of the free energy and, therefore, represent the free energy at an arbitrary time instant $t=t_{*}$ in the form [19]:

$$
f\left(t=t_{*}\right)=f^{C}+f^{H},
$$

where $f^{c}$ - free energy, given by the current values of the strain tensor; $f^{H}$ - free energy, given by the history of changes in the loads on the body.

Considered model representation corresponds to the following position:

1. The new model description takes into account, as a special case, simpler models, in particular, elastic systems $\left(\right.$ at $\left.f^{H}=0\right)$.

2. If the object is not under load $\left(f^{C}=0\right)$, then this does not mean that it is in a state of thermodynamic equilibrium, it is taken into account by the term $f^{H}$.
Let's note that $f^{H}$ is possible at the model level to interpret as well as the value $\lambda_{B}$ in the expression (1).

Let's assume that $f^{H}$ depends on the internal structure - the structure of the material and connect the $f^{H}$ with damage with a scalar variable using the following expression:

$$
f^{H}=f^{H}\left(\omega,|\vec{\nabla} \omega|, \frac{1}{V_{0}} \int_{V} \omega \mathrm{d} V\right),
$$

where $\omega$ - level of damage; $\vec{\nabla}$ - Hamilton operator; $V_{0}-$ characteristic size of the investigated area; $|. .$.$| - module$ vector symbol.

Expression (4) takes into account the fact that the free energy of the body at a point depends on local structural changes, as well as changes in a certain area.

This expression is in accordance with modern trends in the development of materials science, solid state physics and mechanics [20, 21]. In accordance with them, the mechanical behavior of the body is affected not only by the absolute value of the magnitudes, but also by their gradient, as well as the average distribution of the magnitude in a certain neighborhood [22, 23].

This is especially pronounced in areas that are characterized by a high level of energy, as well as by the distribution of degradation structural characteristics in local volumes [24].

Let's note that the distribution of non-local characteristics of the degradation of the structure in a given neighborhood can also be obtained using physical research methods, in particular, the LM-hardness method [25].

\section{Research results}

Let's write the relation (2) with the view of the representation (3):

$$
\sigma=\frac{\partial f}{\partial \dot{e}}=\frac{\partial f^{C}}{\partial \dot{e}}+\frac{\partial f^{H}}{\partial \dot{e}} .
$$

For an isotropic elastic body:

$$
\frac{\partial f^{0}}{\partial \hat{e}}=K e \hat{I}+2 G\left(\hat{e}-\frac{1}{3} e \hat{I}\right)
$$

where $K$ - bulk compression modulus; $G$ - shear modulus; $e=\hat{e} \cdot \hat{I}=\vec{\nabla} \cdot \vec{u}-$ the first invariant of the stress tensor; $\hat{I}-$ unit tensor.

To transform the second expression (5), the set of variables describing non-local material damage is represented as:

$$
\vec{\omega}^{*}=\left(\omega,|\vec{\nabla} \omega|, \frac{1}{V_{0}} \int_{V} \omega \mathrm{d} V\right),
$$

where $\vec{\omega}^{*}$ - vector of generalized damage.

To simplify the recording, let's make the following notation:

$$
a_{1}=\omega, a_{2}=|\vec{\nabla} \omega|, a_{3}=\frac{1}{V_{0}} \int_{V} \omega \mathrm{d} V .
$$

As a result, expression (7) will have the following form:

$$
\vec{\omega}^{*}=\left(a_{1}, a_{2}, a_{3}\right) .
$$


Following the approaches that are presented in [19], the second term relation (5) is presented in the form:

$$
\frac{\partial f^{H}}{\partial\left|\vec{\omega}^{*}\right|} \cdot \frac{\partial\left|\vec{\omega}^{*}\right|}{\partial \dot{e}}=\frac{\left|\vec{\omega}^{*}\right|}{1-\left|\vec{\omega}^{*}\right|} K e \dot{I}+\frac{\left|\vec{\omega}^{*}\right|}{1-\left|\vec{\omega}^{*}\right|} 2 G\left(\dot{e}-\frac{1}{3} e \dot{I}\right) .
$$

In expression (10), in order to preserve the invariance of mathematical transformations, a transition was made from the vector of «generalized» damage to its module.

The selection of the multiplier $\frac{\left|\vec{\omega}^{*}\right|}{1-\left|\vec{\omega}^{*}\right|}$ is related to the need at the functional level to take into account the nonlinearity of the dynamics of structural damage, which is shown, in particular, in $[25,26]$.

Taking into account the expression (9), the relation (5) will look like:

$$
\dot{\sigma}=\frac{K}{1-\left|\vec{\omega}^{*}\right|} e \dot{I}+\frac{2 G}{1-\left|\vec{\omega}^{*}\right|}\left(\dot{e}-\frac{1}{3} e \dot{I}\right) .
$$

In the submitted formulation, the damage $\left|\vec{\omega}^{*}\right|$ corresponds to its classical view as a reduction of the «recall» of the material of the structure to the effect of the load.

Let's analyze the obtained model relations. Taking into account the results (7), (8), expression (11) will look like:

$$
\dot{\sigma}=\left(\frac{1}{1-\left(\sum_{i=1}^{3} \alpha_{i} a_{i}\right)^{1 / 2}}\right)\left(K e \dot{I}+2 G\left(\dot{e}-\frac{1}{3} e \dot{I}\right)\right) .
$$

In the expression (12) in the mathematical representation $\left(\sum_{i=1}^{3} \alpha_{i} a_{i}\right)^{1 / 2}$, a generalized interpretation of the vector modulus in the functional space is shown by the introduction of additional numerical constants $\alpha_{i}, i=1,2,3$.

Let's note that this representation can be interpreted as weighted using the appropriate approximation coefficients [27], which allows more widely than other existing model concepts to take into account the structure of the boundary region of polycrystalline systems.

To obtain the calculated dependencies according to relations (5) $-(12)$, we use the equilibrium equation:

$$
\vec{\nabla} \cdot \dot{\sigma}=0
$$

and obtain:

$$
\left.\begin{array}{l}
\vec{\nabla} \cdot\left(\frac{K(x)}{1-\sqrt{\alpha_{1}(\omega(x))^{2}+\alpha_{2}(|\vec{\nabla} \omega(x)|)^{2}+}}(\vec{\nabla} \cdot \vec{u}) \dot{I}+\right. \\
+\frac{2 G(x)}{1-\alpha_{3}\left(\frac{1}{V_{0}} \int_{V} \omega \mathrm{d} V\right)^{2}}\left(\overrightarrow{\alpha_{1}(\omega(x))^{2}+\alpha_{2}(\mid \vec{\nabla} \omega(x))^{2}+}+\left(\vec{\nabla} \otimes \vec{u}-\frac{1}{3}(\vec{\nabla} \cdot \vec{u}) \dot{I}\right)\right) \\
+\alpha_{3}\left(\frac{1}{V_{0}} \int_{V} \omega \mathrm{d} V\right)^{2}
\end{array}\right)=0,(14)
$$

where $\vec{u}$ - displacement vector; $\otimes-$ symbol of the tensor product.

The above equation is the basis for calculations and the establishment of the stress-strain state of the material at the meso level, taking into account the non-locality of damage in the grain-boundary regions.

The developed model made it possible to analyze the influence of the properties of local volumes of grains on the propensity of steel to break up grains during impact testing of samples in the temperature range from $100{ }^{\circ} \mathrm{C}$ to $-196{ }^{\circ} \mathrm{C}$. Steel $40,40 \mathrm{X}, 40 \mathrm{XГ}, 40 \mathrm{XГP}, 40 \mathrm{XC}$ after quenching and tempering at $600{ }^{\circ} \mathrm{C}$, as well as about friable processing (repeated tempering at $550{ }^{\circ} \mathrm{C}$ with subsequent slow cooling) was investigated.

On the basis of experimental studies [28], a functional dependence of the fraction of secondary intergranular failure $V$ on the relative gradient of properties of alloys $g$ in local volumes was obtained. It is established that, depending on the relative gradient of properties in local volumes, steel can be divided into three groups: with a small, stable, and catastrophic tendency to intergranular destruction (Fig. 1).

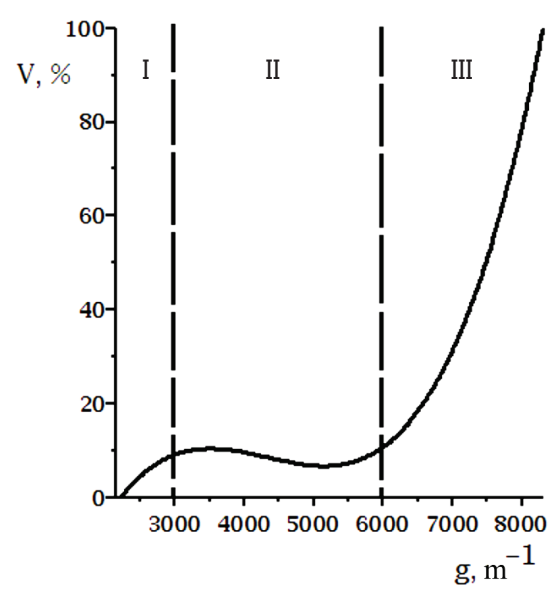

Fig. 1. The dependence of intergranular damage $V$ on the parameter $g$ : I - zone of small (minor) intergranular destruction; II - zone of stable intergranular destruction; III - a zone of catastrophic intergranular destruction

Determining the dislocation density in local volumes of the investigated steels using the method proposed in [29,30] shows that the dislocation density at the grain boundaries is higher after all heat treatment conditions. In the fragile state, the density of dislocations increases more significantly for steels prone to secondary fracture (Table 1).

Table 1

Influence of heat treatment modes on microhardness, dislocation density in local volumes of grains and intergranular destruction of Steel 40 and $40 X$

\begin{tabular}{|c|c|c|c|c|c|c|}
\hline \multirow{2}{*}{$\begin{array}{c}\text { Steel } \\
\text { grade }\end{array}$} & \multirow{2}{*}{$\begin{array}{c}\text { Steel } \\
\text { state }\end{array}$} & \multicolumn{2}{|c|}{$\begin{array}{r}\text { Microhardness, } \\
10^{7} \mathrm{~N} / \mathrm{m}^{2}\end{array}$} & \multicolumn{2}{|c|}{$\begin{array}{c}\text { Dislocation } \\
\text { density, } \mathrm{cm}^{-2}\end{array}$} & $\begin{array}{c}\text { The share of } \\
\text { intergranular } \\
\text { damage, \% }\end{array}$ \\
\cline { 3 - 7 } & Grain & Boundary & Grain & Boundary & \\
\hline \multirow{2}{*}{40} & Viscous & 235 & 246 & $2.21 \cdot 10^{11}$ & $2.43 \cdot 10^{11}$ & 2 \\
\cline { 2 - 7 } & Fragile & 237 & 266 & $2.25 \cdot 10^{11}$ & $2.84 \cdot 10^{11}$ & 12 \\
\hline \multirow{2}{*}{$40 \mathrm{X}$} & Viscous & 246 & 265 & $2.26 \cdot 10^{11}$ & $2.62 \cdot 10^{11}$ & 10 \\
\cline { 2 - 6 } & Fragile & 249 & 288 & $2.31 \cdot 10^{11}$ & $3.10 \cdot 10^{11}$ & 55 \\
\hline
\end{tabular}


The calculations have shown that the proposed model and experimental dependencies of the tendency of steels to intergranulars on the characteristics of local volumes at the meso level are described by a physically justified parameter - the relative gradient of properties. It has a direct connection with the density of dislocations in the boundary zones of the grains, as well as their damage.

\section{SWOT analysis of research results}

Strengths. Calculated model ratios are proposed, which allow for calculations of media with regard to their structure, and analyze their stress-strain state.

Weaknesses. At different variations of the coefficients $\left\{\alpha_{i}\right\}$, let's obtain various mathematical models of media. So, at $\left\{\alpha_{1}=1, \alpha_{2}=\alpha_{3}=0\right\}$ let's obtain the equation of the «classical» model of damaged media, and at $\left\{\alpha_{1}=\alpha_{2}=\alpha_{3}=0\right\}-$ the equation of the elasticity theory. Let's note that the choice of the above factors at the moment is an open question, since the determination of the influence of structure characteristics on the performance parameters of materials is a scientific problem that has not been fully resolved [31].

Opportunities. Using the developed models, physically substantiated parameters for estimating changes in local properties in the grain boundary regions are determined, allowing one to estimate the propensity for the formation of intergranular damage to alloys by technological treatments that change the structural-energy state of the polycrystal grain boundaries.

Let's note that the continual assessment of the behavior of polycrystalline systems with the simultaneous use of three parameters of the structure - damage, its gradient and average damage in the vicinity is quite a knowledgeintensive issue for further research.

The limiting values of the characteristics of local volumes of grains, at which the ability to form intergranular damage to alloys, is determined. This ensures the possibility of introducing innovative technologies for grainboundary design of the structure of metal products, which makes it possible to significantly increase the reliability parameters of parts in comparison with the known technologies - durability, service life, reliability with minimal economic costs.

Threats. The main limiting factor that has the most significant impact on the implementation of the techniques proposed in the work in engineering practice is the need to conduct a procedure for determining the mechanical properties of polycrystalline systems at the meso level. As well as mathematical and computer modeling of such systems, taking into account their structure.

\section{Conclusions}

1. Based on the approaches of thermodynamics, a mathematical model of the mechanics of polycrystalline systems is constructed, which takes into account the non-locality of the distribution of damage in the material of the studied area. The obtained dependences, as a special case, take into account classical and more «simple» models of media and are in accordance with modern ideas about the structure of the material structure at the meso level.

2. The proposed model relationships that allow for calculations of the media, taking into account their structure, and analyze their stress-strain state. Using the developed models, physically substantiated parameters for estimating changes in local properties in the grain boundary regions are determined, allowing one to control the propensity to form intergranular damage to alloys by technological treatments that change the structural-energy state of polycrystal grain boundaries.

3. It is established that, depending on the parameters of the physical and mechanical characteristics of the local volumes of the structure, polycrystalline materials are divided into three groups - with a small, stable, and catastrophic tendency to intergranular destruction. Improving the operational reliability of alloys requires a reduction in the relative gradient of the properties of the grain-grain boundary zone.

\section{References}

1. Watanabe T. Grain Boundary Design For Desirable Mechanical Properties // Le Journal de Physique Colloques. 1988. Vol. 4. P. 507-519. doi: http://doi.org/10.1051/jphyscol:1988562

2. Lejcek P. Grain Boundary Segregation in Metals. Springer, 2010. 249 p. doi: http://doi.org/10.1007/978-3-642-12505-8

3. Makarov P. V. Ob ierarkhicheskoy prirode deformatsii i razrusheniya tverdykh tel // Fizicheskaya mezomekhanika. 2004. Vol. 7, Issue 4. P. 25-34.

4. Kozlov E. V. Izmel'chenie zerna kak osnovnoy resurs povysheniya predela tekuchesti // Vestnik TGU. 2003. Vol. 8, Issue 4. P. 509-513.

5. Entsiklopedicheskiy slovar' po metallurgii. Moscow: Intermet Inzhiniring, 2000. $821 \mathrm{p}$.

6. Computational and theoretical aspects of a grain-boundary model that accounts for grain misorientation and grain-boundary orientation / Gottschalk D. et. al. // Computational Materials Science. 2016. Vol. 111. P. 443-459. doi: http://doi.org/ 10.1016/j.commatsci.2015.09.048

7. Kobayashi R., Warren J. A., Craig Carter W. A continuum model of grain boundaries // Physica D: Nonlinear Phenomena. 2000. Vol. 140, Issue 1-2. 141-150. doi: http://doi.org/10.1016/ s0167-2789(00)00023-3

8. Shtremel' M. A. Prochnost' splavov. Chast' I. Defekty reshetki. Moscow: MISIS, 1999. 384 p.

9. Kozlov E. V., Zhdanov A. N., Koneva N. A. Bar'ernoe tormozhenie dislokatsiy. Problema Kholla-Petcha // Fizicheskaya mezomekhanika. 2006. Vol. 9, Issue 3. P. 81-92.

10. Korneva N. A., Tishkina L. I., Kozlov E. V. Spektr i istochniki poley vnutrennikh napryazheniy v deformirovannykh metallakh i splavakh // Izvestiya RAN. Seriya fizicheskaya. 1998. Vol. 62, Issue 7. P. 1350-1356.

11. Mughrabi H. A two-parameter description of heterogeneous dislocation distributions in deformed metal crystals // Materials Science and Engineering. 1987. Vol. 85. P. 15-31. doi: http:// doi.org/10.1016/0025-5416(87)90463-0

12. Kocks U. F. The relation between polycrystal deformation and single-crystal deformation // Metallurgical and Materials Transactions B. 1970. Vol. 1, Issue 5. P. 1121-1143. doi: http:// doi.org/10.1007/bf02900224

13. Hirth J. P. The influence of grain boundaries on mechanical properties // Metallurgical Transactions. 1972. Vol. 3, Issue 12. P. 3047-3067. doi: http://doi.org/10.1007/bf02661312

14. Weinberg F. Grain boundaries in metals. Canada Department of Mines and Technical Surveys, 1958. 79 p. doi: http://doi.org/ $10.4095 / 306660$

15. Rabotnov Yu. N. Mekhanizm dlitel'nogo razrusheniya // Voprosy prochnosti materialov i konstruktsiy. Moscow: Izd-vo AN SSSR, 1959. P. 5-7.

16. Kachanov L. M. O vremeni razrusheniya v usloviyakh polzuchesti // Izv. AN SSSR. OTN. Mekhanika i mashinostroenie. 1958. Issue 8. P. 26-31.

17. Fizyko-matematychne modeliuvannia skladnykh system / ed. by Burak Ya. Y., Chapli Ye. Ya. Lviv: Spolom, 2004. 264 p.

18. Peleshhak R. M., Lukiyanets B. A. Elektronnoe pereraspredelenie v okrestnosti yadra lineynoy dislokatsii // Pis'ma v zhurnal tekhnicheskoy fiziki. 1998. Vol. 24, Issue 2. P. 37-41. 
19. Kuzin N. O. Ob odnoy matematicheskoy modeli izmeneniya svoystv materiala // Prikladnaya mekhanika. 2015. Vol. 51, Issue 4. P. 125-132.

20. Afaghi-Khatibi A., Ye L., Mat Y.-W. An Effective Crack Growth Model for Residual Strength Evaluation of Composite Laminates with Circular Holes // Journal of Composite Materials. 1996. Vol. 30, Issue 2. P. 142-163. doi: http://doi.org/10.1177/ 002199839603000201

21. Chang K.-Y., Llu, S., Chang F.-K. Damage Tolerance of Laminated Composites Containing an Open Hole and Subjected to Tensile Loadings // Journal of Composite Materials. 1991. Vol. 25, Issue 3. P. 274-301. doi: http://doi.org/10.1177/002199839102500303

22. Xia S., Takezono S., Tao K. A nonlocal damage approach to analysis of the fracture process zone // Engineering Fracture Mechanics. 1994. Vol. 48, Issue 1. P. 41-51. doi: http://doi.org/ 10.1016/0013-7944(94)90141-4

23. Legan M. A. Correlation of local strength gradient criteria in a stress concentration zone with linear fracture mechanics Journal of Applied Mechanics and Technical Physics. 1994. Vol. 34, Issue 4. P. 585-592. doi: http://doi.org/10.1007/bf00851480

24. Kharlab V. D. Gradientnyy kriteriy khrupkogo razrusheniya // Issledovanie po mekhanike stroitel'nykh konstruktsiy i materialov. Saint Petersburg: Sankt-Peterburgskiy gosudarstvennyy arkhitekturno-stroitel'nyy universitet, 1993. P. 4-16.

25. Lebedev A. A., Shvets V. P. Otsenka povrezhdennosti konstruktsionnykh staley po parametram rasseyaniya kharakteristik tverdosti materialov $\mathrm{v}$ nagruzhennom i razgruzhennom sostoyaniyakh // Problemy prochnosti. 2008. Issue 3. P. 29-37.

26. Maugin G. A. The thermomechanics of plasticity and fracture. Cambridge: Cambridge University Press, 1992.350 p. doi: http:// doi.org/10.1017/cbo9781139172400
27. Egorov A. I. Optimal'noe upravlenie lineynymi sistemami. Kyiv: Vyshha shkola, 1988. 278 p

28. Kuzin O. A. Rol' izmeneniya svoystv lokal'nykh ob'emov zeren $\mathrm{v}$ protsessakh interkristallitnogo razrusheniya staley posle uluchsheniya // European multi science journal. 2018. Issue 15. P. 27-29.

29. Ivanova V. S. Mekhanika i sinergetika ustalostnogo razrusheniya // Fiziko khimicheskaya mekhanika materialov. 1986. Issue 1. P. 62-68.

30. Ivanova V. S. Sinergetika razrusheniya i mekhanicheskie svoystva. Moscow: Nauka, 1989. 167 p.

31. Volkov I. A. Uravneniya sostoyaniya vyazkouprugo-plasticheskikh sred s povrezhdeniyami. Moscow: Fizmatlit, 2008. 424 p.

Kuzin Oleg, PhD, Associate Professor, Department of Applied Materials Science and Materials Engineering, Lviv Polytechnic National University, Ukraine, ORCID: http://orcid.org/0000-00033669-0237

Lukiyanets Bohdan, Doctor of Physics and Mathematics, Professor, Department of Applied Physics and Nanomaterials, Lviv Polytechnic National University, Ukraine, ORCID: http://orcid.org/ 0000-0001-6584-7366

Kuzin Nikolay, Doctor of Technical Sciences, Associate Professor of Department, Department of Rolling Stock and Track, Lviv Branch of Dnipropetrovsk National University of Railway Transport, Ukraine; Senior Researcher, Lviv Scientific Research Institute of Forensic Expertise, Ukraine, ORCID: http://orcid.org/0000-0002$6032-4598$ 